\author{
NATALIIA PANAS, \\ Lviv Polytechnic National University (Lviv, Ukraine) \\ e-mail: bellapuh@gmail.com,ORCID 0000-0003-2288-7282
}

\title{
FIGURE OF GENERAL OLEXANDER GREKOV IN HISTORIOGRAPHY OF INDEPENDENT UKRAINE
}

The article presents a complex of scientific work for studying the military-political activity of General A. Grekov, outlines the main problems that a researcher will encounter in the analysis of the general's figure, identifies the features and tendency of historiographic research in the field of military biography of the period of independent Ukraine. The scientific value of each source is analyzed and a brief description of the thematic works is given. The historiography of the period of independent Ukraine has an inherent desire to make up for the gaps of its development in the period of the USSR. Many scientific works are published on the professional activity of the senior military leadership during the National Liberation Competitions of 1917-1921. Despite the continuing study of military construction issues during the revolution, the personnel potential of the Armed Forces, many issues remain poorly understood, or even not at all. Accordingly General Olexander Grekov's name is largely mentioned by historians in the context of the historical events in which he participated directly, without creating a separate holistic study. The pioneer in the study of the life path of the General was Yaroslav Tynchenko. Subsequently, he was joined by Mykhailo Kovalchuk and Olexander Diedyk, who, although not comprehensively investigated the militarypolitical activities of the general, but in their works made considerable efforts to present his achievements during the Ukrainian Revolution. Most of electronic resources selectively describe 0 . Grekov's life, are of a popular science character, and are aimed at an unprepared reader. Individual works also do not exhaust the problem, since they are biographical directories or collections of essays, therefore limited in scope, do not cover the full life and activities of the general. Thus, there is an urgent need to create a separate special study on these topics, which will help to shape the military doctrine of an independent Ukraine and help to fully and objectively reproduce the picture of the events of a hundred years ago.

Keywords: general; military-political activity; Ukrainian revolution; independence.

Introduction

Military-political activity of general O. P. Grekov in Ukrainian historiography of time of independence belongs to the scantily explored scientific problems. It would seem that in the conditions of obtaining an independent state, more or less favorable national policy and opening of access to the archives, the military biography of national liberation competitions was thoroughly investigated. However such sign figure, have not got a sufficient attention of scientists. Until now there is not a single complex research that would show the degree of illumination of the person of Oleksandr Grekov in Ukrainian historiography. As, the analysis of historiography makes it possible to determine the degree of elaboration of the investigated problems, indicate specify works and define them scientific value, we consider this task actual.

In recent years, Ukrainian society's interest in military history has increased, as a result of Russia's military aggression in eastern Ukraine and in the Crimea and of the centenary marking of the Ukrainian Revolution of 19171921. However, future researchers, along with the desire to investigate these personnel, will encounter the problem of lack of literature and unsatisfactory state of information about activities of this military commander. In such situation, most authors quite often limit themselves to published data, often repeating long-known truths.

The purpose of this article is to provide the fullest possible set of bibliographies of the period 1991-2019, which would allow to comprehensively and objectively explore the vital and professional path of General Grekov Olexander Petrovych in a period of his service in the Ukrainian armies.

Two fundamental principles of historical research scientific objectivity and historical are fixed in basis of the article, and also the historical-chronological, comparativehistorical and induction methods are applied.

\section{Results and Discussion}

In December this year marks the 144th anniversary of the birth of General Grekov. Despite the fact that during his entire period of service in the Ukrainian Armed Forces and the titanic work in the military building, $\mathrm{O}$. Grekov was on high command and official positions, his name is undeservedly partially forgotten. Commander of the Second Serdiutska Division, Commander-in-Chief of the army of effective army of the Ukrainian People's Republic, Minister of Military Affairs of the UNR, Head of the Galician Army, extraordinary professor of science, a person of outstanding military talent, who combined both military and juridical education. He was born in Chernihiv, in Glukhiv district in 1875. After October Revolution in Russia, he became a supporter of Ukrainian independence, and for almost two years served in the Ukrainian armies. After Chortkiv offensive, he first emigrated to Romania and than moved to Austria in Vienna in May 1920. Oleksandr Petrovych did not abandon his political activity abroad, becoming a 
member of the All-Ukrainian National Council, founded in 1921 , and also worked in the publishing houses of the "Khliborobska Ukraina" and "Silske gospodarstvo v Ukraini" newspapers. Until 1930 he was engaged in agriculture on the outskirts of Vienna, during 1930-1933 he was unemployed. In 1939 he initiated the creation of military units of the Ukrainian Cossacks, but the attempt failed. In August 1948, he was abducted by Soviet special services (Aleksandr Petrovich Grekov, 2015). After eight years of exile to the Ozerlag camp, he returned to Vienna, where he died in 1959.

A thorough study of the military-political activity of General Olexander Grekov in the context of his service in the Ukrainian armies of the period of national liberation competitions of 1917-1921 requires a comprehensive study of a number of specialized literature. it should be noted that national military topics until the early 90 's of the twentieth century has been the subject of research by Ukrainian historians for the most part in emigration (Melnyk, 2011: 1). In extremely difficult conditions of internment, the remnants of the Ukrainian armies of 1917-1921 worked fruitfully to preserve military-theoretical thought, which subsequently gave a powerful impetus to the development of the Ukrainian military science (Ibid: 2). After proclamation of independence, historians got possibility of objective illumination of the past due to opening of archives and declassifying of separate funds. Many different historical studies have been published. However, the name of the general was mentioned only in the context of the brilliant organization of the Chortkiv offensive operation. A qualitative breakthrough was the publication of a study by researcher Yaroslav Tinchenko, describing his vital path and career, his professional activity in the Russian Imperial Army, his career and his achievements on the fronts of World War I (Tynchenko, 2011). This scientific work is factually rich, author clearly conveyed the historical background and the conditions in which Olexander Petrovych acted, many historical parallels are given. Yaroslav Tinchenko has done considerable labour in Ukrainian and Russian archives. However, this publication is inaccurate, it does not claim the full exhaustiveness of the material, since the author did not use some of the most informative funds in the Central State Archive of Supreme Authorities and Governments of Ukraine (Central Executive Committee of Ukraine) in Kyiv, which directly reflect his orders during the command of Ukrainian Galician Army, Army of UNR, also made a number of factual errors.

In 1993-1995 Ya. Tynchenko also published the following materials dedicated to General Grekov: a brief biography (Tynchenko, 1993), articles and separate protocols of interrogations of Olexander Petrovych on his archival investigative case (1948-1949), (Tynchenko, 1995) an essay in the book-collection of biographies "Ukrainian Officership: Ways of Sorrow and Forgetting" (Ibid).

Information, which partly reflects the military activity of the general, is found in the writings of the "First UkrainianBolshevik War (December 1917 - March 1918)", (Tynchenko, 1996) "Officer Corps of the Army of the Ukrainian People's Republic (1917-1921)", (Tynchenko, 2007) "Ukrainian Armed Forces, March 1917 - November 1918 (Organization, Numbers, Fighting)" (Tynchenko, 2009), "Troops of the Honorable Mr. Hetman. Army of the Ukrainian State, May-December 1918" by the same researcher (Tynchenko, 2014).

Since 1995, the first studies on the top military management of modern history of Ukraine have been published. Lviv historians O. Kolyanchuk, M. Lytvyn, and K. Naumenko published a brief biography of the general in their work
"The Generality of Ukrainian Liberation Competitions", giving an overall assessment of his activity as the Leader of Galician Army (Kolianchuk, Lytvyn, Naumenko, 1995).

In 1998, M. Lytvyn wrote a thorough monograph sanctified to history of the Ukrainian-Polish war of 1918 1919 (Lytvyn, Naumenko, 1998). The process of beginning the reorganization of the army under General Grekov command and military operations on the Polish-Ukrainian front during the June offensive are reproduced. However, there is no detailed analysis of Grekov's work in position of Initial head of Galician Army.

After the 2000s, Ukrainian military biography received a new breath. Thus, during the last eighteen years dissertations that investigated activity of that time top military management (Myron Tarnavskyi, Mykhailo Omelianovych-Pavlenko, Symon Petliura, Petro Skoropadskyi and others) were protected. A deep comprehension and analysis of forming of the armed force of period of liberation competitions gave an opportunity to soldiers to begin the theoretical prosecution of working of military doctrine and to lay the foundations of building of regular military force with all its components.

In 2004 there was the published work of M. Lytvyn and K. Naumenko "The Military Elite of Galicia", in which researchers provided biographical information on the command staff of the Ukrainian Galician Army. The authors, based on archival materials and memoirs of the general, tried to present his biographical data, but again, in a general perspective, without exploring the cause-and-effect relationship of the general's activities with the general political conjuncture at that time (Lytvyn, Naumenko, 2004).

In 2008, a four-volume book of V. Soldatenko "Ukraine in the Revolutionary Age: Historical Essay Chronicles" was published. Author, on the basis of attracting a wide range of sources, presents information concerning activity of Olexander Petrovych as UNR Minister of Defense, his participation in the negotiations of the Directory with the French command in Odessa in 1919 and a number of other interesting facts (Soldatenko, 2008).

Perhaps the most informative source for exploring Grekov's figure is his own memoirs. General left his little known in Ukraine "Memories", which he wrote at different times of his expatriate life. One fragment of these memoirs, titled "Spring 1918 in Ukraine", was published in the 11th issue of "Za Derzhavnist'" (Grekov, 1964), published in Toronto. Other parts of the memoirs were published in Russian in 1965-1966 in the White-immigrant edition of the "Vestnik Pervopohodnika", published in Los Angeles. These are the sections "In Ukraine in 1917" (Grekov, 1965), "Negotiations of the Ukrainian Directory with the French command in Odessa in 1919" (Ibid), "Petliurovschina" (Ibid), "Eight years of exile in the Soviet Union" (Ibid). The "Vestnik Pervopohodnika" was printed on a shapirograph with a print run of 100-300 copies. Even in the specialized Russian libraries is still not complete set of "Herald". In Ukraine, it does not exist at all. All issues of the "Bulletin" were collected only by the Russian historian O. Deryabin (Tynchenko, 2011: 347). For the first time in Ukraine they were printed by Yaroslav Tynchenko, he published important documents of the criminal investigation of the general of the archives of the VUChK-GPU-NKVD-KGB and his biographical memories, which occupy the days of the Ukrainian Revolution and the reference to Ozerlag (Parkhomenko, 2011: 105).

At the beginning of 2010th secret services continue to be given out about the separate figures of top political and military management of time of national liberation revolution 1917-1921. Greater part of such labours is 
revolved round a few sign figures of Ukrainian military history, while other figures are not given enough attention (Parkhomenko, 2010).

In 2014, a book by researcher O. Stetsyshyn, "Landsknehta of the Galician Army," went out, in which the author limited himself only to short bibliographical information about the general Grekov (Stetsyshyn, 2012).

The high scientific level, rich facts and involvement of the optimal spectrum of methodological foundations are characterize works of historian M. Kovalchuk, in which many interesting points can be found concerning the professional activity of Olexander Petrovych. In general, his writings carefully describe the process of Ukrainianization of individual parts of the Russian Imperial Army (RIA) after the February Revolution. The author also published a more complete version of the General's memoirs, which makes it possible to clearly follow the negotiation process in Odessa between the Directory and the French landing force. M. Kovalchuk also published some archival cases of the Russian State Military History Archive concerning the activities of Ukrainian Galizian Army under the command of O. Grekov (Kovalchuk, 2012).

In 2016, the author team, consisting of A. Rukkas, M. Kovalchuk, A. Papakin, V. Lobodaev, published a sound study, which also contains brief information regarding General Grekov's career path (Kovalchuk et al., 2016).

Separate questions, tangents to General Grekov's military activities are analyzed in articles by V. Parkhomenko.

The tipping point in Ukrainian military science is the work of Lviv researcher Olexander Diedyk "Chortkiv Offensive", in two parts (Diedyk, 2013; 2016). Work that has been written for more than a decade has carefully reproduced the process of Grekov leadership of the UGA. An author not only presented the facts of the UGA's activity, but also gave an objective professional assessment of the achievements of the general in the position of the Chief Leader, extremely clearly reproduced the course of the fighting during the operation, analyzed the scale of reforms that the general at the head of the UGA had implemented. The book is invaluable for exploring General Grekov's military activities.

Some information about the life of Olexander Petrovych can be found in the memoirs of contemporaries of the revolution in Ukraine of 1917-1921, which were reissued during the period of independence. In addition, a few memoirs of other Ukrainian figures can be traced to a passing mention of General Grekov. Such memories were later reprinted and acquired the new sounding after 1990th.

In the last decade, regional editions of historical, biographical and local lore about the participants of the liberation competitions of individual localities have also been popularized. These works are of indisputable value in identifying the personnel of combat units and studying a wide range of military-political processes.

\section{Conclusion}

Thus, apart from the works of Ya. Tynchenko, M. Kovalchuk and O. Diedyk, at the present stage, with ample opportunity for deep research and objective coverage of many historical processes, Ukrainian historical science leaves the activity of this this military leader on periphery of eyeshot. Most works are limited only to brief references and short mentions about Olexander Grekov, and only occasional references or brief biographical details about the General can be found in them. Electronic resources are mostly represented by a few small articles that are general in nature, without covering any particular aspects of this person.
But they do not exhaust the problem, as they are biographic reference books or collections of essays, consequently limited in scope, do not cover the full life and professional activities of prominent General of Ukraine, being of a popular science-fiction character.

\section{REFERENCES}

Aleksandr Petrovič Grekov. Retrieved from http://agso.uni-graz.at/ spannkreis/biografien/g/grekov_aleksandr_petrovic.html (In Deutch).

Diedyk, O. G. (2013). Chortkivska ofenzyva, Pt.1., 232 p. (In Ukrainian).

Diedyk, O. G. (2016). Chortkivska ofenzyva, Pt.2., 192 p. (In Ukrainian).

Kovalchuk, M. Memoirs of General Grekov. Retrieved from http:/ /militarist.milua.org/via/VIA_16_grekiv_pdf (In Ukrainian).

Kovalchuk, M. (2012). The Ukrainianization of the 34th Corps of the Russian Army (August-November 1917). Mandrivets, 4: 43-49. (In Ukrainian).

Kolianchuk, O., Lytvyn, M., Naumenko, K. (1995). Generality of Ukrainian Liberation Competitions: biographies of generals and admirals of Ukrainian military formations of the first half of the twentieth century. Lviv, 283 p. (In Ukrainian).

Lytvyn, M. R., Naumenko, K. (2004). Galicia's military elite. Lviv, 376 p. (In Ukrainian).

Lytvyn, M. R., Naumenko, K. (1998). Ukrainian-Polish War of 1918-1919. Lviv, 469 p. (In Ukrainian).

Melnyk, R. P. (2011). Ukrainian Military Theoretical Thought of the 20-30s of the XX Century: the author's dissertation abstract on obtaining the scientific degree of candidate of historical sciences. Lviv, 19 p. (In Ukrainian).

Rukkas, A., Kovalchuk, M., Papakin, A., Lobodaiev, V. (2016). To fight for freedom. Victory through defeat. Ukraine in the wars and revolutions of 1914-1921. Kharkiv, 352 p. (In Ukrainian).

Parkhomenko, V. A. (2010). The tumultuous years of 1917-1921 in the life of General O. Grekov (based on memoirs). Visnyk Cherkaskoho universytetu, Seriia Istorychni nauky, 192: 7178. (In Ukrainian).

Parkhomenko, V. A. (2011). Memoirs of General O. Grekov as a Source from the History of the Ukrainian Revolution of 19171921. In: Literatura ta kultura Polissia: zbirnyk naukovykh prats, No 61: 105-118. (In Ukrainian).

Soldatenko, V. F. (2010). Ukraine in the Revolutionary Age: Historical Essay Chronicles. In 4 volumes: Vol. II. Year 1918. Kyiv, 411 p. (In Ukrainian).

Stetsyshyn, O. (2012). Military mercenaries of the Galician army. Lviv, 480 p. (In Ukrainian).

Tynchenko, Ya. (2001). General Alexander Grekov: Military activity and destiny. Retrieved from http://memorial.kiev.ua/zhurnal/ pdf/02_2001/343.pdf (In Ukrainian).

Tynchenko, Ya. (1993). Short biography of Grekov O.P. Narodna Hazeta, № 39, 10 p. (In Ukrainian).

Tynchenko, Ya. (1995). General's last fight: General Olexander Grekov. In: Ukrainske ofitserstvo: shliakhy skorboty ta zabuttia. Pt. 1. Kyiv, pp. 259-263. (In Ukrainian).

Tynchenko, Ya. (1995). General's last fight. Records of interrogations of O. Grekov. Akademyia, 2: 5-35. (In Ukrainian).

Tynchenko, Ya. (1996). The First Ukrainian-Bolshevik War (December 1917 - March 1918). Kyiv-Lviv, 371 p. (In Ukrainian).

Tynchenko, Ya. (2007). Officer Corps of the Army of the Ukrainian People's Republic (1917-1921): biogr. directory. Pt. 1. Kyiv, 535 p. (In Ukrainian).

Tynchenko, Ya. (2014). Ukrainian Armed Forces, March 1917 November 1918 (organization, size, fighting). Kyiv, 455 p. (In Ukrainian).

Tynchenko, Ya. (2014). The troops of the Reverend Mr. Hetman. Army of the Ukrainian State, May-December 1918. Kyiv, 151 p. (In Ukrainian). 


\section{LIST OF REFERENCE LINKS}

Дєдик О. Г. Чортківська офензива. Частина І. Львів: Астролябія, 2013. 232 с.

Дєдик О. Г. Чортківська офензива. Частина ІІ. Львів: Астролябія, 2015. 192 с.

Ковальчук М. Спогади генерала Грекова. URL: http://militarist.milua.org/via/VIA_16_grekiv_pdf (дата звернення: 27.10.2019)

Ковальчук М. Українізація 34-го корпусу російської армії (серпень-листопад 1917 р.). Мандрівець. 2012. № 4. С. 43-49.

Колянчук О., Литвин М., Науменко К. Генералітет українських визвольних змагань: біограми генералів та адміралів українських військових фрормацій першої половини XX століття. Львів: Ін-т українознавства, 1995. 283 с.

Литвин М. Р., Науменко К. Є. Військова еліта Галичини. Львів, 2004. 376 c.

Литвин М., Науменко К. Українсько-польська війна 1918-1919 pp. / Ін-т українознавства ім. І. Крип'якевича НАН України, Ін-т Схід.-Центр. Європи. Львів, 1998. 469 с.

Мельник Р. П. Українська військово-теоретична думка 20-30их рр. XX ст.: авторефрерат дис. ... к. і. н.: 20.02.22 / Національний університет "Львівська політехніка". Львів, 2011. $19 \mathrm{c}$.

На бій за волю. Перемога через поразки. Україна у війнах і революціях 1914-1921 років / авт. кол.: А. Руккас, М. Ковальчук, А. Папакін, В. Лободаєв. Харків, 2016. 352 с.

Пархоменко В. А. Буремні 1917-1921 рр. в житті генерала О. Грекова (за матеріалами мемуаристики). Вісник Черкаського університету. Вип. 192. Серія Історичні науки. 2010. C. 71-78.

Пархоменко В. А. Мемуари генерала О. Грекова як джерело 3 історії української революції 1917-1921 років. Література та культура Полісся: збірник наукових праць. Вип. 61. Ніжин, 2011. С. 105-118.

Солдатенко В. Ф. Україна в революційну добу: Іст. есе-хроніки. У 4-х т.: Т. ІІ. Рік 1918. Київ: Світогляд, 2010. 411 с.

Стецишин О. Ландскнехти галицької армії / Центр досліджень визвольного руху. Львів: Часопис, 2012. 480 с.

Тинченко Я. Генерал Олександр Греків: військова діяльність і доля. URL: http://memorial.kiev.ua/zhurnal/pdf/02 2001/ 343.pdf (дата звернення 25.10.2019).

Тинченко Я. Стислий життєпис О. П. Грекова. Народна Газеma. 1993. № 39. $10 \mathrm{c}$.

Тинченко Я. Останній бій генерала: Генерал-хорунжий Олександр Греків. Українське офріцерство: шляхи скорботи та забуття. Ч. 1. Київ, 1995. С. 259-263.

Тинченко Я. Останній бій генерала. Протоколи допитів О. Грекова. Академія. 1995. № 2. С. 5-35.

Тинченко Я. Перша українсько-більшовицька війна (грудень 1917 -березень 1918). Київ-Львів, 1996. 371 с.

Тинченко Я. Офіцерський корпус Армії Української Народної Республіки (1917-1921): біогр. довідник. Київ: Темпора, 2007. Кн. 1. 535 c.

Тинченко Я. Українські збройні сили, березень 1917 р. - листопад 1918 р. (організація, чисельність, бойові дії). Київ: Темпора, 2009. 455 c.

Тинченко Я. Ю. Війська Ясновельможного Пана Гетьмана. Армія Української Держави, травень-грудень 1918 р. Київ: Темпора, 2014. 151 с.

Aleksandr Petrovič Grekov. URL: http://agso.uni-graz.at/spannkreis/biografien/g/grekov_aleksandr_petrovic.html (дата звернення 30.10.2019).

Наталія Панас,

Національний університет "Львівська політехніка" (м. Львів, Україна)

e-mail: bellapuh@gmail.com, ORCID 0000-0003-2288-7282

\section{ПОСТАТЬ ГЕНЕРАЛА ОЛЕКСАНДРА ГРЕКОВА В ІСТОРІОГРАФІЧНІЙ НАУЦІ НЕЗАЛЕЖНОїУКРАЇНИ}

Історіографії періоду незалежної України притаманне прагнення надолужити прогалини свого розвитку у період СРСР. У світ виходять чимало наукових праць, присвячених професійній діяльності вищого військового керівництва доби національно-визвольних змагань 1917-1921 рр. Незважаючи на продовження вивчення питань військового будівництва періоду революції, кадрового потенціалу Збройних Сил, багато питань залишаються малодослідженими, або й зовсім недослідженими. Так, ім'я генерала Олександра Грекова історики в основному згадують у контексті історичних подій, в яких він брав безпосередню участь, не створивши окремого цілісного дослідження, присвяченого діяльності цього видатного військовика. Піонером у дослідженні житєєого шляху генерала став Ярослав Тинченко, згодом до нього долучилися Михайло Ковальчук та Олександр Дєдик, які хоч і не комплексно дослідили військово-політичну діяльність генерала, проте у своїх працях доклали значних зусиль для презентації його здобутків у період української революції. Щодо електронних ресурсів, то більшість із них вибірково описують життя О. Грекова, носять науково-популярний характер і розраховані на непідготовленого читача. Окремі праці також не вичерпують проблему, оскільки є біографічними довідниками або збірниками нарисів, відтак обмежені в обсязі, не охоплюють сповна життя і діяльність генерала. На сучасному етапі назріла нагальна потреба у створенні окремого спеціального дослідження, присвяченого зазначеній тематиці, що сприятиме формуванню воєнної доктрини незалежної України та допоможе повніше та об'єктивніше відтворити картину подій столітньої давнини. У статті наведено комплекс наукового доробку для вивчення військово-політичної діяльності генерала О. П. Грекова, вказано основні проблеми, з якими зустрінеться дослідник під час аналізу постаті генерала, визначено особливості та тенденцію історіографічних досліджень у галузі військової біографістики періоду незалежної України. Проаналізовано наукову цінність кожного джерела, надано коротку характеристику тематичних праць.

Ключові слова: генерал Греков; військово-політична діяльність; українська революція; незалежність.

(c) Nataliia Panas

Надійшла до редакції: 08.11.2019

Прийнята до друку: 26.11.2019 